\title{
$9 \mathrm{~B}$
91
$15 S_{3}$ \\ $9 \mathrm{~B}$
91
$15 \mathrm{~S}_{3}$ \\ UC-NRLF

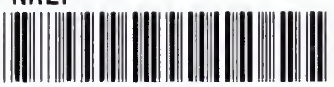 \\ कB $48 \quad 630$ \\ $9 \mathrm{~B}$
91
$15 S_{3}$
}



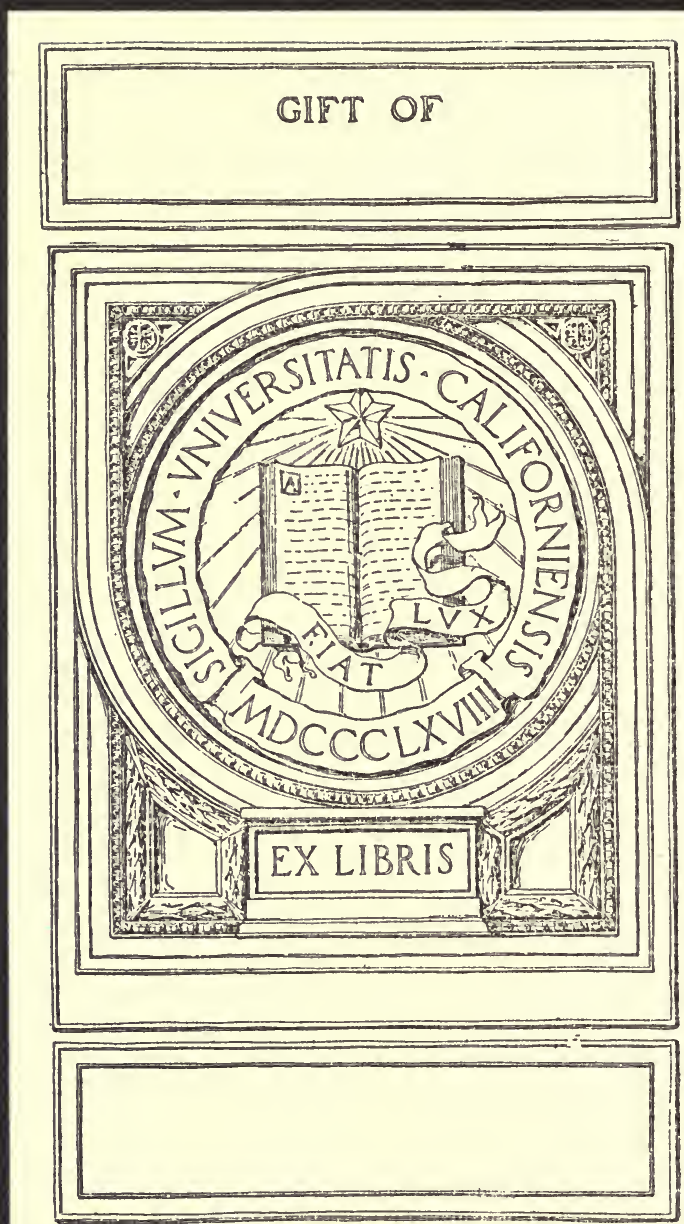

$806 l^{\prime} 12$ ' $\mathrm{NHC}$ 'IHd

- $X$ 'N 'כsnoex 


\title{
UNITED STATES DEPARTMENT OF AGRICULTURE SYLLABUS 11 (Revised)
}

Coutribution from the State Relation: Service A. C. TRUE, Director

Washington, $\mathrm{D}$. C.

\section{ILLUSTRATED LECTURE ON WHEAT CULTURE}

\author{
By
}

J. I. SCHULTE, Assistant Agriculturist, Office of Experiment Stations, States Relations Service

\section{CONTENTS}

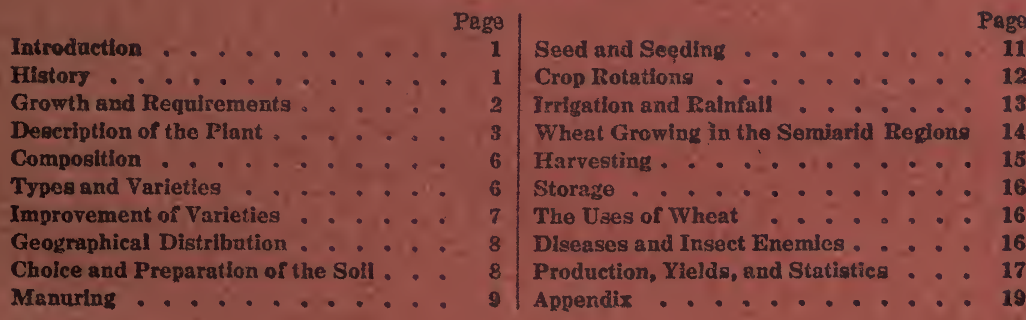

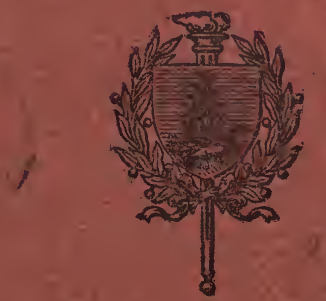





\section{U. S. DEPARTMENT OF AGRICULURE,}

STATES RELATIONS SERVICE,

A. C. TRUE, Director.

\section{SYLLABUS 11-ILLUSTRATED LECTURE ON WHEAT CULTURE. ${ }^{1}$}

By J. I. Schulte, Assistant Agriculturist, Office of Experiment Stations, States Relations Service.

\section{INTRODUCTION.}

Wheat is the world's choicest bread crop and the source of View. one of the principal foods of the most progressive and intelligent nations. The United States is the leading wheat-produc-ing country of the world, and it is of the greatest importance that its rank in this respect be maintained. Year by year the requirements are growing, and, as production is not increasing at the same rate as consumption and exportation, wheat culture should be placed on a more efficient basis. Earlier in our history the total yield was increased by bringing new lands under cultivation and devoting them largely to wheat culture, but such lands are no longer available in sufficient area to be of great significance in this connection and attention must now be given to increasing the production of the country by other ways and means. . The average yield per acre at present is only about 15 bushels, whereas in some European countries it is double this quantity, and even more. With the average yield per acre of England this country would be capable of more than doubling its annual total production. The wheat soils of this country can be made as productive as those of other countries, and to bring this about on a profitable basis is one of the important problems of American agriculture.

\section{HISTORY.}

Wheat is probably a native of western Asia, and its cultivation is very ancient. The Chinese are said to have grown

\footnotetext{
1 This syllabus has been prepared by direct cooperation between the author, J. I. Schulte, as regards subject matter, and J. M. Stedman, Farmers' Institute Specialist of the States Relations Service, as regards pedagogical form. It is designed to aid farmers' institute and other extension lecturers in presenting this subject before popular audiences. The syllabus is illustrated with 16 lantern slides. The numbers in the margins of the pages refer to the lantern slides as listed in the Appendix.
}

$27849^{\circ}-18-1$ 
view whent also. known by different names in most ancient languages. Furthernoro, the grain itself has been found in prehistoric works and monuments. So far as known, the crop was not grown in America before the discovery by Columbus.

\section{GROWTH AND REQUIREMENTS.}

Wheat requires moisture, air, light, heat, and plant food for its development. Most of these factors are more or less under control. Moisture under certain conditions is regulated by cultivation, drainage, and irrigation. Air is admitted into the soil by means of drainage and tillage. Light has free access to the parts of the plants that require it. . The degree of heat necessary for germination and growth is influenced to a certain extent by the choice of the season for planting and by cultivation to reduce evaporation, and plant food is supplied from the quantity of nutritive elements naturally stored in the soil and maintained and replenished by the different methods of soil fertilization and management.

The plant body is composed of cells containing during their life a substance called protoplasm, having the remarkable power of changing the foods taken up by the plant into the substances used in building up the cell wall and at the same time providing for those entering into its own composition.

Two general groups of substances are formed within the plant, namely, the carbohydrates and the proteids. The carbohydrates, of which starch and sugar are good examples, are composed of carbon, hydrogen, and oxygen; and the proteids, in addition to these three elements, contain nitrogen and sometimes also sulphur and phosphorus. Much of this elaborated soluble material is used in the nourishment and growth of the plant. The surplus is carried to the storage organs, such as the bulbs, roots, fruits, seeds, etc., where in some cases it is deposited in solid form. In wheat and other grains the storage organ is the kernel.

By growth of the plant we understand an increase in the number of cells in the plant structure. The building up of organic substances, such as carbohydrates and proteids, from the elements of organic and inorganic material, is the most important part of the process. Water taken up by the roots moves within the plant through the ducts and the cell walls, according to the laws of capillarity, osmosis, and diffusion, and passes out through the leaves.

The water, on entering the roots, carries inorganic matter in solution, and gases, especially carbon dioxid, are taken into 
the leaves from the air. As these substances are subjected in Vlew. the leaves to the combined action of light and chlorophyll, the formation of the carbohydrates takes place. Less is known about the formation of proteids; but it is believed that they are formed in the leaves much in the same way as the carbohydrates, although light does not act so directly in their production. The proteids are produced in much smaller quantities than carbohydrates, but they are nevertheless of greatest importance to the life of the plant.

\section{DESCRIPTION OF THE PLANT.}

\section{GERMINATION.}

The vegetative life of the plant begins with the germination of the seed, and for this process moisture, air, and the proper temperature, all operative at the same time, are required. The parts of the wheat kernel of prime importance $n$ germination are the embryo, or germ, which develops to form the young plant, and the endosperm, or starchy reserve material, which serves as the source of food for the embryo in the first stages of growth. The embryo is composed of a vegetative portion, or that part containing in minute form the leaves and roots of the new plant, and the scutellum, which during germination brings the starch or flour of the endosperm into solution and transfers it to the growing parts.

The first step in germination is the absorption of water, of which the wheat kernel takes up from five to six times its own weight. The outer layers of the kernel are ruptured and the vegetative portion of the embryo begins to develop its minute leaves and roots by means of the food derived from the endosperm, until finally parts of the young plant appear above the ground and become green, thus showing that chlorophyll or leaf-green has been formed. The chlorophyll is a substance playing an important part in the formation of new organic matter in the plant. At this stage the roots begin to take up inorganic matter held in solution in the soil water which they absorb, and under the action of air and light the young plant changes this inorganic matter into the organic matter of plant tissue. All the nutritive material in the endosperm has now been consumed. The process of germination is completed and the plant is self-supporting.

THE ROOTS.

The germinating kernel of wheat produces a whorl of several small temporary roots, which are followed by a set of permanent roots thrown out from the crown, a joint or group 
view. of joints in the young stem usually about an inch below the surface of the scil. The depth of the crown depends mainly on the depth of planting. Roots may start from any joint or node under or at the surface of the ground. In the early stages of the plant the development of the roots is much greater than the growth of the leaves, the roots of many plants having obtained a length of 20 inches when the portion of the plants above the ground is not over 5 inches in height. The permanent root system is fibrous ind branching, the branches occurring mainly in the upper 2 feet of soil. Wheat commonly is considered a short-rooted plant, but its roots extend from 4 to 5 feet into the ground and go much deeper than those of the ordinary hay grasses. A cop ous and continued moisture supply in the soi' tends to produce shallowrooted plants, while smaller and barely sufficient supplies of soil water induce deeper rooting. The crop does not thrive where conditions of the subsoil, such as a hardpan too near the surface, interfere with the development of the root system. If the seeding is shallow the temporary and the permanent roots form practically a single tuft, but if the seeding is deep many of the permanent roots or those growing from the crown are from one-half to 2 or 3 inches above the temporary whorl. As soon as the permanent roots have become well established, the temporary roots and the seed kernel are no longer of any benefit to the growing plant.

THE STEMS.

The structure of the stems or culms varies with the kind of wheat. In some types the stems are thin-walled and hollow and in others either thick-walled or pithy. In all types the stems are jointed, the joints being known as the nodes and the parts between the joints as the internodes. The first stem, or the one growing up directly from the seed, does not always reach complete development, but a number of other stems are thrown up from the crown and grow up to maturity. This action of the plant, known as tillering or stooling, varies with the variety and the season. At full growth well-developed wheat plants are from 3 to 5 feet high, with about five to six internodes in the erect portion of the stem.

THE LEAVES.

The leaves consist of the sheath, the blade, the ligule, and the auricle. The sheath starts from the nodes or joints and clasps the stem. The opening of the sheath is on the opposite side from the blade, which is the part extending outward from the stem and which varies in size, shape, texture, and vena- 
tion. The ligule is a thin, transparent tissue, clasping the View. stem where the blade and the sheath join, and the auricle is a fine, hairy projection located at the base of the blade. The first leaves, which come from the crown, are set close together, being produced from the nodes before the internodes have lengthened. As the stem or stems grow up the leaves become larger and are distributed at intervals, marking the length of the internodes.

THE HEAD OR SPIKE.

The head of wheat consists of the rachis, which is a notched extension of the stem, and the spikelets arranged upon it. The notches or angles correspond to the nodes and the short sections separating the notches to the internodes. When the internodes of the rachis are short the heads are compact or crowded, and when they are long the heads are said to be open. The spikelets are the flower clusters, which ultimately produce the grain. Their number ranges from 8 to 10 on each side of the rachis in some varieties, and from 10 to 16 in others. Each spikelet, as a rule, has five flowers, but the upper or odd one is rarely fertile.

THE FLOWER OR BLOSSOM.

The flower or blossom consists of the reproductive organs, namely, the ovary, the pistil, and the stamens. The ovary is the rudimentary grain of wheat and with the pistil constitutes the female portion of the blossom, while the stamens represent the male element. The pistil branches into two feathery styles and is borne on the ovary, while the stamens, of which there are three, have their filaments inserted around the base of the ovary and extend around and above it so that the anthers are placed around the pistil.

THE GRAIN.

The kernel of wheat is the fruit of the plant. Its outer covering is made up of two layers, the outer the epiderm or pericarp, and the inner the endocarp. Beneath these layers is the testa or seed covering, and all three of these coverings go to make up the bran in milling and constitute about 5 per cent of the entire grain. Immediately under the testa, or seed covering, is a layer of cells rich in gluten, which, in milling, is partly removed with the bran and contributes largely to the feeding value of this product. The interior portion of the grain surrounded by the gluten cells, called the endosperm, is composed mostly of starch but contains also some proteid substances. The endosperm, which constitutes about 75 per cent of the kernel, is the source of flour. The germ. 
View. which is located on the opposite side of the furrow or crease and at the end opposite to the brush or hairy tip, forms only a

11 small part of the kernel. The grain varies in size and shape

12 with the type and the variety.

\section{COMPOSITION.}

Variety, climate, and soil are the principal factors which determine the composition of the wheat plant. Normally the grain of wheat contains about 10 per cent of water, 2 per cent of ash, 12 per cent of protein, 2 per cent of fiber, 72 per cent of nitrogen-free extract, and 2 per cent of fat. The gluten is made up from the protein and the starch content is included under nitrogen-free extract. The gluten is a mixture of two proteids, gliadin and glutenin, and its quantity and quality determine the value of the grain for baking purposes. The quality of the gluten is governed to some extent by the proportion of gliadin and glutenin-a gluten consisting approximately of one-fourth glutenin and three-fourths gliadin being considered most satisfactory. The starch is located almost wholly in the endosperm, which constitutes about 75 per cent of the entire kernel, and nearly all of which is made into flour in the process of milling. The nitrogen-free extract is largely made up of starch, the amount of which varies from 60 to 70 per cent.

Ordinarily the straw, including the chaff, constitutes from 50 to 65 per cent and the grain from 35 to 50 per cent of the wheat plant. The straw contains normally from 10 to 15 per cent of moisture, and in addition approximately 4 per cent of ash, 3.5 per cent of protein, 40 per cent of crude fiber or cellulose, 45 per cent of nitrogen-free extract, and 1.5 per cent of fat. The chaff contains more phosphoric acid and also a little more protein but less crude fiber than the straw.

\section{TYPES AND VARIETIES.}

The varieties of wheat are divided into groups according to 13 botanical characters, and in some cases these again are divided 14 according to characteristics due to environment or geographical distribution.

Owing to the wide geographical distribution of the plant, the varieties of wheat are more numerous than those of any other cereal except rice. In addition to the botanical classification, a number of other classifications are in use, as, for instance, the market classification embracing the different types recognized by the grain markets, such as soft winter, hard winter, hard spring, and white wheats; the classification based on external characters, which groups the varieties into 
spring and winter wheats, bearded or awned and beardless or View. awnless varieties, white and red wheats, hard and soft sorts, early and late varieties, etc. The soft wheats also are called starchy wheats and the hard wheats glutinous wheats. The common wheats include all varieties excepting those used in the preparation of macaroni, spaghetti, and other pastes.

Varieties of wheat differ greatly in productiveness, hardiness, drought resistance, resistance to lodging, quality of grain, and in other characters. There are always best varieties for certain soils and regions but no varieties that succeed best under all conditions. It costs no more to grow a good variety than a poor one, and it is therefore to the farmer's interest to obtain the best sort for his locality. All varieties grown in the vicinity should be observed and the best one selected. Varietal strains in their own locality are likely to give better results than strains of the same variety brought from a distance because there is little or no change in environment.

\section{IMPROVEMENT OF VARIETIES.}

Wheat varieties are improved mainly by selection and crossing. Improvement by selection comprises the selection of seed and the selection of individual plants. Varieties may be improved by selection or by crossing and selection together. Most varieties now grown are the result of simple selection, and this kind of work is often very profitable and replete with satisfaction. Dawson Golden Chaff, for instance, had its origin in a single stool of White Clawson wheat which had been the only one to survive winter in a bare and exposed position. This variety has given excellent results in New York, Michigan, and Canada, and is a standard sort in many localities. This instance is one of the many showing the importance of selecting individual plants.

The crossing of varieties is effected by means of artificial cross-fertilization. The stamens must be removed from the 16 the blossom before the pollen sacks are mature enough to break and to pollinate the pistil. After this is done the pistil must be protected from the pollen of other flowers borne either in the same or in other heads. Usually all the flowers not desired for crossing are removed and the entire head is then wrapped in tissue paper and the pollen of the variety chosen as the male parent applied to the stigmas when these are in proper condition. As soon as the application of pollen is made the heads are carefully covered to keep other pollen from entering and possibly fertilizing the blossom. The resulting seed is planted and the crops for several years are subjected to rigid selection to fix the variety. 
Although wheat is grown under a very wide range of climatic conditions, the bulk of the world's crop is produced in the temperate zones. The quality of wheat in the different

22 parts of the world varies with the climate, and even in this country wheat differs in quality in the various wheat-producing sections.

\section{CHOICE AND PREPARATION OF THE SOIL.}

Light fertile clay and medium fertile loam soils of good depth and well drained are best adapted to wheat culture. Heary clays are too compact and are inclined to bake, and highly fertile loams tend to lodge the crop. Light clay soils having the proper degree of compactness and being sufficiently retentive of moisture are better adapted to winter wheat than are the loams. The clay soils are usually uplands, and the loam soils are either lowlands or prairies. The alluvial soils of river bottoms, if not too rich, usually make good wheat lands, because they are deep and fertile and generally made up of clay, sand, and humus in proportions, making them friable and porous and giving good drainage. The loams are primarily corn lands, but in connection with corn culture are well suited to spring wheat. Very light, loose or sandy soils and wet, peaty, sour lands are unfit for the wheat crop.

Drainage is necessary to a profitable development of the wheat plant, and a permeable subsoil is especially important during the most active stages of its growth and to winter wheat also in the late fall and winter. Where the subsoil is not sufficiently permeable, proper drainage should be provided by putting down tile, as this is generally the most satisfactory and economical method of draining.

The character of the soil influences the yield to a greater extent than it affects the quality, which is largely controlled by climatic conditions. That the two factors are closely connected is shown by the durum wheats, which require rich humus soils and hot and dry seasons. Soils high in organic matter tend to increase the protein content and the hardness of the grain.

Land for wheat should be plowed several weeks before sowing time in order to bring about the most favorable conditions for a rapid and regular germination of the seed. After plow-

23 ing, the soil should be allowed to settle and the moisture content at the surface to increase before the seed is sown. By harrowing or disking the land at intervals from the time 24 it is plowed until it is seeded down weeds are destroyed and 
soil moisture is conserved, while the seed bed is made smooth, fine, and even. Numerous small clods on the surface, however, may be of value in holding the snow on winter wheat fields and in preventing or reducing soil washing.

Deep plowing is not of general value and often seems to affect the yield of straw more than the yield of grain. Plowing from 4 to 6 inches deep is adequate, especially if the land is in good tilth. Subsoiling is expensive and frequently unprofitable in wheat culture. On friable and mellow soils plowing is unneccessary if the land was well cultivated the year before in connection with growing corn or other hoed crops. On such land a seed bed can be prepared by disking or cultivating and harrowing.

If the plowing is done when it is too wet the soil is likely to harden or bake, and if done when too dry the ground remains rough and lumpy. It should be remembered that in growing wheat and other similar plants the tillage of the crop, as it were, is performed before and at the time the seed is sown. In the semiarid regions the success of the crop depends often entirely upon the careful and thorough cultural treatment given the land.

\section{MANURING.}

The fertility of wheat land may be maintained and improved by the use of barnyard manure, commercial fertilizers, and green manures, and by proper crop rotations and fallowing. No generally applicable rule for fertilizing wheat lands can be laid down, but certain underlying principles are operative everywhere. Wheat straw contains approximately 0.6 per cent of nitrogen, 0.2 per cent of phosphoric acid, and 0.6 per cent of potash, and the grain about 2 per cent of nitrogen, 0.85 per cent of phosphoric acid, and 0.55 per cent of potash. This means that a ton of straw removes from the soil 12 pounds of nitrogen, 4 pounds of phosphoric acid, and 12 pounds of potash, and a ton of grain, or $33 \frac{1}{3}$ bushels, 40 pounds of nitrogen, 17 pounds of phosphoric acid, and 11 pounds of potash. These figures call attention to the importance of returning at least the straw in the form of manure to the land and also point to the fact that continued wheat growing for the market must deplete the fertility of the soil.

Barnyard manure is preferably applied to the corn crop before wheat. When manure is directly applied to winter wheat it should be spread and plowed under immediately after the preceding crop is removed, in order that it may become well embedded in the soil before the seed is sown. In such cases the use of 10 tons per acre is sufficient and generally $27849^{\circ}-18-2$ 
View. will give better results than double that quantity. When barnyard manure is used as a top-dressing for wheat it should be well rotted and finely divided, and preferably spread with a wide-tired manure spreader. On most loams and alluvial soils on which wheat is grown in rotation the use of barnyard manure, especially its direct use, is unnecessary, but on light clay soils it of ten proves profitable.

The application of large quantities of available nitrogen, either in commercial fertilizers or barnyard manure, usually results in a heavy growth of straw and a consequent tendency to lodge. A complete fertilizer, or one containing nitrogen, phosphoric acid, and potash, is generally to be recommended, and while no rule applicable to all cases can be laid down, the use of 300 to 500 pounds of a fertilizer mixture furnishing in plant food 3.3 per cent of nitrogen, 12 per cent of available phosphoric acid, and 4 per cent of potash is very common. Ordinarily on poor soils the application of nitrogen and potash may be relatively high, but on soils in a fairly good state of fertility the quantity of these elements may be reduced. Commercial fertilizers are more profitable as a rule on clay soils than on the richer loams, and throughout the western wheat area of the country they are little used. Applications 26 of 25 to 40 bushels of lime per acre are of ten very beneficial, especially on soils treated with sulphate and chlorid of ammonia for a series of years. Top-dressings with nitrate of soda are sometimes given after the crop has made some growth, but if the plants are in a vigorous condition in the spring no top-dressing is necessary.

Green manuring with leguminous crops is very desirable, but when a heavy green crop is plowed under it is best to follow it with a hoed crop before putting the land into wheat. Benefit is derived also when leguminous plants are grown before wheat and other crops and only the stubble is plowed under.

Summer fallowing, which is seldom followed in humid sections, is practiced very extensively in some of the wheat regions on the Pacific coast and in those Western States where dry-farming methods are required. To mature profitable crops the land in some of these sections requires the rainfall of two seasons, and hence wheat generally is grown on land that has had a season of rest and has stored up sufficient moisture to supply the demands of the crop. Cultivation of the summer fallow is practiced to conserve the soil moisture and to increase the store of available plant food. On lands that receive adequate rainfall summer fallow can not be as profitable as the culture of some leguminous crop, which not only adds 
nitrogen and humus to the soil, but also prevents, or at least View. largely reduces, leaching.

\section{SEED AND SEEDING.}

Seed wheat, besides being all of one variety, also should be heavy, plump, and free from dirt, weed seeds, and injured or immature kernels. A pure variety is always to be preferred to a mixture of varieties, however slight this may be. Heavy seed promotes stooling and the production of strong plants, and increases yield and quality of grain as well as yield of straw. In most cases where heavy seed has been compared with small or light seed, the results have been in favor of the heavy seed. Some injured or immature seed may sprout successfully, but, due to insufficicnt food supply or imperfectly developed germs, the plants soon die. Wheat that has become heated or moldy in storage may not grow at all or else have only a low percentage of germination. It is advisable, therefore, to make a germination test to determine the vitality and the viability of the seed. This may be done by placing the kernels between folds of cloth or blotting paper, one end of which is placed in water so that the moisture is supplied through capillarity, and keeping this improvised germinator at the ordinary room temperature, never allowing it to fall below $50^{\circ} \mathrm{F}$. Wheat cleaned with a fanning mill is used for seed generally, but a much better way, although little practiced, is to select each year from the best plants grown on a special seed plat the best seeds for use in planting the seed plat for the following season, and use the rest of the seed-plat crop for sowing the general field.

The time of sowing is determined by the season, the variety of the wheat, the nature and fertility of the soil, the altitude and latitude of the locality, and sometimes by the prevalence of insect enemies, especially the Hessian fly, and existing weather conditions. In the North winter wheat is sown earlier and spring wheat later than in the South. In the southern winterwheat regions the seed is preferably sown late in September or early in October; in Ohio, Indiana, Illinois, Iowa, and Nebraska, from September 10 to 20; and in some of the extreme northern winter-wheat regions, as early as the last week in August or the first week in September. Spring wheat generally is sown as soon in the spring as the seed bed can be prepared properly.

The germination, stooling process, and underground growth of winter wheat takes place when the soil temperature is from $42^{\circ}$ to $50^{\circ} \mathrm{F}$. When this temperature prevails for a sufficient length of time during winter the wheat stools and produces 
View. underground growth, and when the continued warmer weather of spring arrives the different stems shoot upward and develop their leaves and lengthen their internodes rapidly.

The depth of sowing depends mainly upon the kind of soil and its physical condition. The object always should be the provision of the best moisture conditions for the seed. In moist soils or soils of a hard texture shallow seeding is practiced, but in loose or dry soils deeper seeding is necessary. The usual depth of sowing wheat is from 1 to 2 inches. When the seed kernel lies deep the portion of the young stem connecting it with the crown is necessarily longer than when it lies nearer the surface of the ground, as in the case of shallow seeding. Heaving of the surface soil; due to frost or other cause, may break the young stem, separating the crown and other parts of the plant from the primary root system. This condition is detrimental to the plant it if occurs before the permanent roots are large enough to take up the necessary food and moisture.

The quantity of seed used per acre depenc's upon the kind of soil and its physical condition, the climate and the season, the time and method of sowing, the variety, and the size and quality of the seed. As a general rule wheat is sown thicker on poor soils, stiff and cold clay lands, and rough and cloddy seed beds than on fertile soils, friable loams, and fields well worked and smoothed before seeding. Late sowing and broadcasting also require more seed than early sowing and drilling. A large-grained variety requires a greater quantity of seed than a fine-grained sort, and a variety with limited stooling capacity more than a heavy stooling variety. The proper quantity of seed per acre varies from 3 to 8 pecks.

Two common methods of sowing wheat are drilling and broadcasting. Different kinds of machines are used for both operations, but broadcasting is done also by hand. Drilling is done with common drills, press drills, shoe-and-chain drills, disk drills, etc: Each method has its advantages under certain conditions. The greater portion of the wheat crop is

29 drilled. Winter wheat sometimes is rolled in the early spring to counteract in part the results of winter heaving of the soil. Harrowing wheat in the spring after the crop has made some growth has given favorable results in some instances, but it is not practiced generally. Late rolling and late harrowing are often injurious.

\section{CROP ROTATIONS.}

The place of wheat in the crop rotation is governed largely by the cleanness of the soil, the adaptability of wheat as a 
nurse crop for clover and grass, the possibility of either fall View. or spring sowing, the comparatively early ripening of the crop, the fertility of the soil, and other conditions.

Hoed crops and summer fallow, especially if cultivated, tend to leave a greater quantity of water in the soil than growing broadcasted and uncultivated crops, such as the small grains, In a dry season, for this reason, wheat after corn or cultivated summer fallow is likely to give a much better yield than if grown after wheat or oats. On some new soils wheat sometimes is grown for several years in succession on the same land, but continuous cropping experiments have shown that after a series of years the yields begin to decline, "and rotation experiments have indicated clearly that better yields are obtained from soils under rotation than those growing wheat year after year.

\section{IRRIGATION AND RAINFALL.}

Successful wheat culture does not depend so much upon the total annual rainfall as upon the amount of moisture the soil furnishes the crop during the growing period. The total rainfall in some of the wheat-growing localities of the West and Northwest ranges annually from 12 to 18 inches and yet good crops are produced without irrigation; but in other sections the same amount of rainfall is insufficient for a profitable yield. Again, in many humid regions where the yearly precipitation is as much as 40 inches, most of the water runs off in the drainage, less than half of the total precipitation being available to the growing plants. The question, therefore, is not alone how much rainfall there is, but how much of it is retained by the soil for the use of the crop. The relation of rainfall to wheat culture is largely a question of soil conditions. It is a significant fact that a very large proportion of the wheat of the world, as well as a superior quality of grain, is produced in rather dry regions or on lands subject to extremes of temperature and drought.

Wherever or whenever the rainfall is deficient, irrigation generally insures a crop and secures larger yields and better grain. It must be practiced judiciously, however, to be successful. Furrow irrigation is considered best in some sections and flooding in others. Irrigation sometimes has a marked influence on the composition of the grain. At the time the kernel is filling out, the soil should be properly supplied with moisture to promote the production of full and plump grain. Too much water at this period has a tendency to yellow the crop, retard its maturity, and lower the yield. 
view. Fall irrigation of winter wheat has been found beneficial when the soil lacked moisture for the production of the necessary fall growth. One or two irrigations are sufflcient for winter wheat in the spring. When the water is applied in the evening, about sunset, the evaporation from the surface of the soil is much less than when it is applied during the day, and it also frequently results in a higher yield of straw and grain.

\section{WHEAT GROWING IN THE SEMIARID REGIONS.}

Wheat is the principal crop of our semiarid regions. Its successful production there depends largely upon the use of varieties adapted to the conditions and upon cultural methods based largely on soil moisture conservation. Hard spring wheats and winter wheats are grown. The hard spring wheats grown in the northern part of the Great Plains area include the durum wheats and varieties of the common wheats, those of the Bluestem and Fife groups being prominent. The winter wheats produced over the larger part of our semiarid area are represented mainly by hard winter wheats, as Crimean, Kharkov, Turkey, and others cultivated largely in the Great Plains area; the semihard winter wheats grown in the Great Basin region; and the soft winter wheats extensively produced in the Pacific Coast States.

Cultural operations involve mainly the preparation of the seed bed with a view to furnishing adequate moisture and in the case of winter wheat to provide also protection against unfavorable winter weather. The land for spring wheat should be plowed the preceding summer or fall and afterward given surface cultivation at intervals until seeding time. For winter wheat early and deep fall plowing is desirable in some sections, while in others late and shallow plowing is the more profitable. Much depends on the season and the soil, as seasonal variations give unexpected results and some soils are little responsive to cultural methods. Furrowing with a lister after harvest and leveling the ridges preparatory to seeding is practiced sometimes in preference to plowing and with satisfactory results. Subsoiling in general has not met expectations in overcoming drought, increasing yields, or returning profits. Disking corn ground as a soil preparation instead of plowing has given good yields as a rule and, in addition, has reduced the labor cost. Summer tillage, together with cropping in alternate years - a method in very general use-gives comparatively high average yields, but on account of its high labor cost and the production of a crop only every other year 
does not always net the largest returns. Compared with spring wheat, winter wheat is the more profitable crop on tilled summer fallow. In sections where winterkilling is common, seeding in standing cornstalks or in small grain stubble without preparation is often resorted to as a means of winter protection.

Winter wheat is commonly sown at the rate of 3 pecks and spring wheat of about 4 or 5 pecks per acre. All seed should be drilled.

\section{HARVESTING.}

The time of harvesting wheat is controlled mostly by the latitude and the seasons. The world harvests wheat in every month of the year. In general practice wheat is cut when the heads have turned yellow but while the stems are still slightly green and the kernel in the hard-dough stage. In the greater portion of the wheat-producing area of this country harvesting must be done in from 8 to 10 days to prevent losses from shattering. Varieties grown in some sections, such as the club wheats in the Pacific Coast States, do not shatter so readily as the varieties commonly grown in the Mississippi Valley and Eastern States. The state of ripening influences the composition of the plant. The dry matter in the entire plant increases up to maturity and the kernel increases in starch content as it develops.

In most countries harvesting now is done largely by means of the self-binder, although the header, self-made reaper, and combined harvester and thrasher also are used. In sections where labor is cheap and the machines costly, cutting with the cradle and binding by hand are still practiced. Immediately after cutting and binding, the sheaves are put up into shocks to protect them against dew, rain, and the sun, and to facilitate curing and ripening in the shock. Round shocks usually contain from 12 to 16 sheaves, of which 2 are used as a cap or cover. Long shocks are made by placing 12 or 14 sheaves as pairs in a row, and are used when the sheaves are wet, to facilitate rapid and thorough drying.

The crop is either kept in the shock until thrashed or is stacked when sufficiently dry and thrashed later on. Stacking is a greater safeguard against injury to the crop through bad weather. In a properly built stack there is a slant from any point in the interior toward the outside. A few days after stacking, a slight heating of the grain, commonly called sweating, sets in, and this may continue for one or two weeks. If the wheat is not allowed to sweat in the stack the thrashed grain will sweat in the bin. 
Víew. As in the methods of harvesting, so in the methods of thrashing great changes have taken place. In former times the flail was used or the grain was trodden out by horses or oxen, and these methods are still practiced where agriculture is conducted on a small scale or in a primitive manner. Generally, however, to-day thrashing machines are operated by horse, steam, gas engine, and electric power. A great improvement in machines also has been made, the largest recent improved outfits under favorable conditions being capable of turning out as many as 2,000 bushels in one day. Formerly from 500 to 600 bushels were considered a good day's run.

\section{STORAGE.}

39

40

41

42

In storing wheat the object should be to keep it dry and to prevent insect depredations. Stored wheat of ten changes in weight as a result mainly of variations in moisture content. In dry climates slight gains in weight occur during winter storage, and wheat harvested and cured under arid conditions and then transported to humid climates will at times show marked gains in weight during transit and storage. In humid regions wheat has a tendency to lose in weight after thrashing, but in arid and semiarid climates this tendency is not so apparent.

\section{THE USES OF WHEAT.}

The principal value of wheat lies in its use for the manufacture of flour for bread and pastry. The flour of durum wheat, generally richer in gluten than the flour of common wheats, is used for macaroni, spaghetti, and other pastes. The byproducts of the mill are used for feedirg purposes and the chaff and straw for feed and bedding. Winter wheat also is pastured in southern sections, where it makes a comparatively large growth in the fall or winter, but caution should be used in following this practice.

\section{DISEASES AND INSECT ENEMIES.}

43 The most common diseases of wheat are the rusts and smuts, 44 and the most common insect enemies the chinch bug and the Hessian fly. The common rusts are the orange-leaf rust (Puccinia rubigo-vera) and the black rust ( $P$. graminis). The most injurious smut is the stinking smut or bunt (Tilletia feetens).

45 The loose smut (Ustilago tritici) is much less injurious than the stinking smut. Injuries to the wheat crop from the chinch bug and the Hessian fly are often very extensive. For the prevention of stinking smut seed wheat is either soaked in hot water $\left(132^{\circ}\right.$ to $133^{\circ} \mathrm{F}$.) for 10 to 15 minutes, immersed in a 
solution of formaldehyde in water and the smut balls skimmed View. off (formalin treatment), or dipped in a solution or copper sulphate in water. The loose smut can not be prevented by disinfecting the surface of the seed, but a modified hot-water treatment, consisting of soaking the seed for at least 4 and not over 6 hours in cold water, then draining it and placing it for 10 minutes in water at $129^{\circ} \mathrm{F}$. (never above $131^{\circ} \mathrm{F}$.) may be applied. This modified treatment is not well adapted to large quantities of seed.

Chinch bugs are destroyed by burning them in their places of hibernation and by plowing and harrowing them under after they have occupied decoy strips. The main factors in the control of the Hessian fly are good seed, a well-prepared and fertile soil, and, in the case of winter wheat, sowing after most of the fall brood has disappeared. Spring wheat, however, should be sown as early as possible.

Since the date of safely sowing winter wheat for the escape of the crop generally from Hessian fly varies greatly in the different wheat sections of the United States and even in different localities in a single State, and also since the proper date for a single locality differs from year to year, the county agent should correspond regarding this subject with the entomologist at the agricultural college or experiment station or with the Bureau of Entomology, United States Department of Agriculture, to obtain specific information for his particular county.

\section{PRODUCTION, YIELDS, AND STATISTICS.}

The average yield of wheat for the years 1905-1914, inclusive, in different countries was as follows: Belgium 36.4, United Kingdom 33.4, Germany 30.7, Austria 20.2, France 20.1, Hungary 18.1, United States 14.8, and Russia 9.8 bushels per acre. In 1915, the United States produced $673,947,000$ bushels of winter wheat on $41,308,000$ acres, the average yield being 16.3 bushels per acre; and of spring wheat $351,854,000$ bushels on 19,161,000 acres, the average production being 18.4 bushels per acre. This was the largest wheat crop on record and the largest yield ever produced by any one country. In 1911, Denmark grew 44.6 bushels per acre, Belgium 39.5 bushels, the Netherlands 38.7 bushels, Ireland 36.8 bushels, and Great Britain 32.9 bushels. These average yields indicate that a large number of growers raise 40, 50, and even 60 bushels to the acre. A comparison of the average yields in the United States and these countries, together with the soil and climatic conditions prevailing here and abroad, would 
View. lead to the conclusion that the same high yields can be secured in many sections of this country, provided the same care is given to the selection of the variety and the seed and to the tillage of the soil. In this connection, however, the production per man as well as the production per acre must be taken into consideration. It is estimated that in the United States 9.3 acres of crops are grown per capita of farm population, as compared, for instance, with 2.4 acres in the United Kingdom, and higher yields per acre in the latter country may therefore be expected. The problem before the wheat grower in the United States is the economical increase in production, and economic conditions must determine not only its feasibility but also whether larger returns are to be obtained from each acre or each worker, or from both. 


\section{APPENDIX.}

\section{LANTERN SLIDES.}

No. of

view.

1. Cross sections of wheat grains, showing embryo and endosperm.

2. Wheat roots.

3. Different types of wheat stems.

4. Stem of different lengths.

5. Sheath, auricle, and ligules.

6. The distribution of leaves and the length of the internodes.

7. The rachis.

8. Crowded and open heads and types of spikes.

9. Spikelets.

10. Reproductive organs of wheat.

11. Different types of wheat grains.

12. Grains of different varieties.

No. 1, Red Fife from North Dakota; No. 2, Zimmerman from Kansas; No.3, Turkey Red from Kansas; No. 4, Fultz from Nebraska; No. 5, Glyndon (638) from North Dakota; No. 6, Rieti from Italy.

13. Grains of different species of Triticum.

No. 13, Polish wheat; No. 14, Einkorn; No. 15, Black Velvet emmer; No. 16, Red Winter Club spelt; No. 17, Volo: No. 18, En grain double.

14. Heads and grains of durum wheat.

15. Soft and hard wheats.

16. Removing the stamens from the blossom.

17. Breaking of pollen sacks.

18. Removing undesirable flowers.

19. Growing the first seed from hybrids.

20. Emasculating and cross-pollinating wheat flowers.

21. Variation in size of head.

22. Map showing the distribution of different types of wheat within the United States.

23. Plowing wheat land.

24. Disking wheat land.

25. Disking cornstalk ground for wheat.

26. Liming land.

27. Testing seed wheat.

28. Germination of plump and shrunken seed wheat.

29. Drilling wheat.

30. Furrow method of irrigating wheat.

31. Effect of irrigation on the composition of wheat.

32. Appearance of grains of different hardness and composition.

33. Self-binders at work.

34. Combined harvester operated by horses.

35. Combined harvester operated with steam power.

36. Cradling wheat. 
37. A primitive method of thrashing wheat.

38. Modern thrashing outfit.

39. Sacked wheat stored in the open.

40. A Chicago grain elevator.

41. A Canadian grain elevator.

42. Grain elevator, Manchester, England.

43. Wheat heads and straw, showing rust.

44. Effect of rust on wheat grains.

45. Shrinking of grains due to rust.

46. Table of production in various countries.

\section{REFERENCES.}

1. The Cereals in America. By T. F. Hunt.

2. The Book of Wheat. By P. T. Dondlinger.

3. The Culture of Winter Wheat in the Eastern United States. U. S. Dept. Agr. Farmers' Bul. 596.

4. Winter Wheat Varieties for the Eastern United States. U. S. Dept. Agr. Farmers' Bul. 616 .

5. Winter Wheat in the Great Plains Area. U. S. Dept. Agr. Bul. 595.

6. Growing Hard Spring Wheat. U. S. Dept. Agr. Farmers' Bul. 678.

7. Spring Wheat in the Great Plains Area. Relation of Cultural Methods to Production. U. S. Dept. Agr. Bul. 214.

8. Varieties of Hard Spring Wheat. U. S. Dept. Agr. Farmers' Bul. 680.

9. Wheat Experiments. Ohio Sta. Bul. 298.

10. Insects Destructive to Grain and Grain Products Stored in Bins and Granaries. Kansas Station Circ. 47.

11. The Change in Weight of Grain in Arid Regions During Storage. Utah Station Bul. 130.

12. Chinch Bug. U. S. Dept. Agr. Farmer's Bul. 657.

13. Hessian Fly. U. S. Dept. Agr. Farmers' Bul. 640.

14. Statistics of Grain Crops. U. S. Dept. Agr. Yearbook 1916.

15. Smuts of Wheat, Oats, Barley, and Corn. U. S. Dept. Agr. Farmers' Bul. 507.

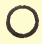








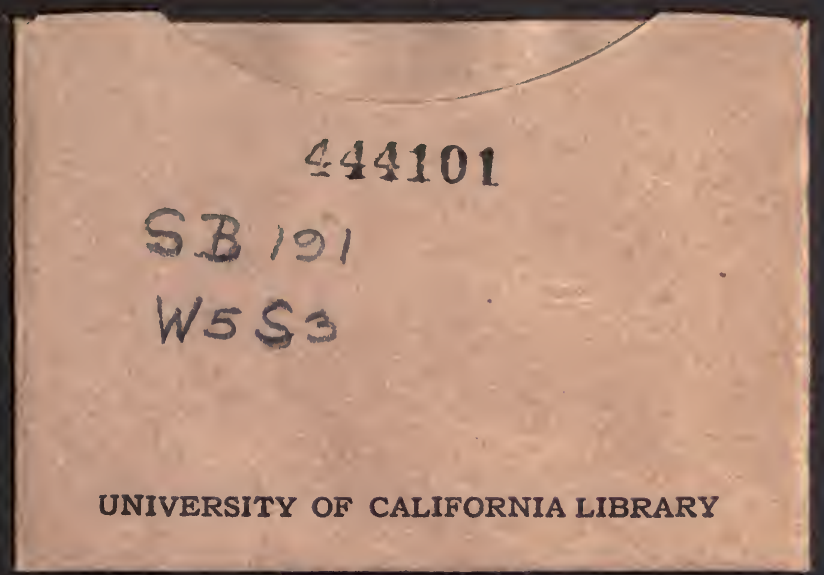

UNIVERSITY OF CALIFORNIA LIBRARY

$$
\begin{aligned}
& S B 191 \\
& \text { W5S3 }
\end{aligned}
$$


